\title{
Countering Youth Radicalisation and Extremism in Northern Nigeria: The Role of Education as a Clinical Intervention
}

\section{Stanley Ehiane \\ ORCID iD: https://orcid.org/0000-0001-6871-4526}

\section{Abstract}

The dynamic nature of youth extremism in Northern Nigeria has been attributed to the low level of education in the region. Research indicates the need for the development of clinical models to address radicalisation and de-radicalisation. Poverty, lack of education, isolation, exclusion, and religion are the key variables that intersect when addressing social issues that contribute to the spread of ideologies and the recruitment of youth into extremist groups. The World Bank Group (WBG) is increasingly being called upon to address the development dimensions of violent extremism by client governments and the international community. The World Bank has shied away from designing a standalone programme to counter violent extremist from an education perspective. The risk of susceptibility to extremist ideology is determined by a multiplicity of factors, the most important being education. In Northern Nigeria education has been compromised and has left the youth vulnerable to armed groups such as Boko Haram. Formal and Qeducation contributes to a climate of increased care and respect for basic human rights and peace. This paper focus on the role of education in the prevention of violent extremism (VE) and discusses the international policy framework on the significance of formal education as a tool for countering violent extremism (CVE) and contributing to peacebuilding in Nigeria. While the study is non-empirical, extensive literature was consulted across the disciplines to address the critical issues in the study. However, the relationship between the identified constructs' conceptual framework was subjected to intensive discourse using the ecosystem theory of Urie Bronfenbrenner. The conclusion drawn is an early warning on the need for 


\section{Stanley Ehiane}

a clinical response model that promotes the acquisition of formal and quality of education for a successful soft approach to counter violent extremism and radicalisation terrorism mechanisms.

Keywords: education, violent extremism and radicalism, prevention of violent extremism

\section{Background}

The increasing rise of extremism in Africa has threatened the continent's attainment of its development aspirations. The phenomenon has also created severe security threats in the region, where more than 33300 deaths have been recorded since 2011 (UNDP 2017). This asymmetrical conflict has further caused widespread displacement and critical humanitarian issues in the 'Horn of Africa'. The origin and manifestation of the extremist groups on the continent began with the intellectual founder of extremist ideology, Sayyid Qutb in Egypt in the 1950s (Al-Mahri 2006). However, when Qutb arrived in Egypt from the United States, where he became more radicalised, he joined the Muslim Brotherhood established by Hassan al-Binna in 1928 (Al-Mahri 2006). However, the Brotherhood desired to create a more Islamic society, governed by the Islamic principles of the old traditions. According to Qutb, Islamic faith and practices had become tainted, and the Western world had diluted Islam as compared to the Islam in the days of Prophet Muhammed. Therefore, according to Qutb, to recapture the former glory of Islam, infidels, nonbelievers, those who do not practise according to Sunni traditions and Muslims in the time of Prophet Muhammed, should be attacked and eliminated through a holy war called jihad (Al-Mahri 2006). Hence, Qutb ideology was fleshed out by Osama Bin Laden and became the foundation for Al-Qaeda. Bin Laden modernised Al-Qaeda and built an ideology to drive what he called traditional Islam, and a moniker for his movement. Of course, it is obvious that both Qutb and Bin Laden's Islamic doctrines are contrary to the practices and dictates of Islam; rather, they have both, like others, misinterpreted the Qur'an to advance their own interests.

The post-Cold War period has seen/witnessed the resurgence of the ideology that produced the Mujahideen. The Mujahedeen were the Afghan militia forces that waged a brutal war against the Soviet army during the 
ideological war between the Union of Soviet Socialists Republics (USSR) and the US between the late 1970s and the 1980s. Bin Laden, with his group of Arab fighters joined the Mujahideen to defeat the Soviet Union Army in 1989, after which Bin Laden returned to Saudi Arabia where he was born in 1957 (Lawrence 2005). Following their victory against the Soviet incursion into Afghanistan, the Mujahedeen resolved to return to their home countries in North Africa to initiate and sustain the radical brand of Islamic fundamentalism that was the norm in the post-cold war international system of states (Sharif \& Richard 2016). Apart from North African countries that actively participated in the Afghan war, many West and Central African countries were also influenced by the radical ideological ferment into the 'jihad' against the invasion by an infidel country. Some of the participants in this global jihad were Mali, Chad, Sudan, Libya, and Mauritania. These countries became the recipients of training and also had access to sophisticated arms and ammunition, which resulted in the rise of another brand of Mujahideen in Africa. The beneficiary was a Salafist group that later became known as Al-Qaeda, in the Islamic Maghreb (Sharif \& Richard 2016). This marked the genesis of Al-Qaeda as a Salafist sect in the continent, which further gained the allegiance of other terrorist groups like the Al-Shabaab in Somalia and Kenya.

In the Lake Chad region, the core fundamentalist movement is the Boko Haram, which is rooted in Salafism, an extremist Islamic ideology in the mould of wahabbism, the dominant religious ideology of the Arabian Peninsula. The Salafists are the earliest generation of Islamists who regarded themselves as practicing a pristine form of Islam that manifests through its consistency with the provisions of the Qur'an and the Sunnah of the Prophet Muhammad (PBUH). They saw themselves as true worshippers and hence the puritans, according to Islamic revivalist tenets (Ehiane 2017). Ehiane further observes that Salafism presents in two forms, those who believe in converting nonbelievers through evangelistic outreaches, and Salafists who subscribe to the orchestration of jihad as fulfilling the divine mandate of spreading their beliefs upon which the sect's ideology leans. Besides, the group objects to Western civilisation, especially the liberal values that define its rudiments which the group perceives as decadent and morally bankrupt. The group's motivation is sustained by the quest for the entrenchment of Islamic culture and belief systems, especially at a time when the contest between Islam and the West is becoming more evident (Murad Idris 2019). Of course, Boko Haram's radical ideology is not a coincidence; the sect's foundation reflects the personality of 


\section{Stanley Ehiane}

its former leader, Sheik Yusuf Mohammed's beliefs. It was gathered that Yusuf Mohammed was a strong follower of al-Ibn Taymiyya, who uncompromisingly believed in the dictates of the Qur'an and Hadith, but who was also a Salafist (Ehiane 2017). Al-ibn Taymiyya was a radical Islamic scholar who strictly adhered to jihad, and Muhammed Yusuf, like Taymiyya, founded the Boko Haram movement based on his teachings. Yusuf's belief system and attitudes were centred on the philosophy underpinning his opposition to Western culture and civilisation. Besides, a large proportion of the radicalised members of the Boko Haram group were drawn from uneducated Almajiri ${ }^{1}$ youths and a few undergraduate students and migrants from neighbouring countries like Chad, Cameroon, and Niger (Ehiane 2017). Furthermore, some of the students that constituted the sect's membership, who were already receiving formal education, withdrew from their various institutions while the graduates tore up their certificates to enlist in the jihad (Onuoha 2010).

According to UNICEF, basic education plays a significant role in children's effective lifelong learning and in ensuring universal basic education for all; therefore, various programmes have been launched globally. The most recent among the global programmes are the Sustainable Development Goals (SDGs) 4 and 5 of 2015. The primary objective of the SDGs goals is to ensure quality education by the year 2030. Nigeria has made considerable efforts over the years with the support of partners such as UNICEF, and the United States Agency for International Development (USAID), towards achieving free universal primary education (UPE) across the country. The pilot project of UNICEF in collaboration with Teaching at the Right Level (TaRL) Africa, and the government. was another innovative programme (UNICEF 2019). Despite efforts to achieve free UPE, Nigeria accounts for more than one in five out-ofschool children in the world, totalling about 13 million, and the conflictaffected northeast region has nearly 75 per cent (UNICEF 2019; UNICEF 2016). Hitherto, out-of-school in Northern Nigeria is also due to parental preference for Qur'anic education over formal education. The out-of-school children are also those pupils who attend the Qur'anic schools and the Almajiri also fall into this category. The predominance of the Islamic faith and its

\footnotetext{
${ }^{1}$ Almajiris (Qur'anic school pupils) (Olorunfemi 2013). The term Almajiris originated from the Arabic context Al-muhajirun to connote cohorts of 'the holy Prophet Muhammed who indeed migrated with the prophet from Mecca to Medina' (Onifade 2015: 10).
} 
concentration in Northern Nigeria has contributed to the increase of Qur'anic schools in the region.

The insurgency in Northern Nigeria has been devastating and has damaged the educational infrastructure. The government has lost over \$272.96 million to infrastructural damage, and more than 600000 children are currently out of school, and some of these children are vulnerable to extremist recruitment (UNICEF \& UNESCO 2012). This unhealthy educational situation calls for intervention to strengthen social cohesion and build peace. Against this background, this study process was developed to understand the youth's inclination towards radicalisation and extremism in Nigeria. Furthermore, the study explores the genesis of Almajiri who form the largest proportion of forces in Boko Haram and why they have failed to acquire formal education. The study also examines the efforts made by the government to ensure formal education in Northern Nigeria, considering the high rate of Almajiris in the region. Lastly, the study gives insight into developing a clinical intervention to promote quality education for peacebuilding in the northern region of Nigeria.

\section{Conceptual Discourse}

Violent extremism, as an academic discourse, emerges when radical behaviour starts to make use of violence as a means of expression after being alienated and ideologically transformed. However, not all radicalised individuals travel along an inevitable path to violent extremism, which is the final phase after radicalisation. Violence gradually moves from being instrumental to becoming symbolic for an extremist (UNDP 2016). This is the situation for many extremist groups like Boko Haram, Al-Shabaab, AQIM, and ISIS, that have branded themselves with violence. A number of these terrorist groups' members may have been engaging in criminal activities, which could have served as early warning signs to security agencies before they seemingly orientated towards the cause of violence. However, the concept of extremism does not have any specific meaning until the violence has been identified as empowerment against others in the pursuit of specific goals. Considering the violent nature of the extremists and their presence across the world, their alliances and affiliations internationally have helped in terms of recruitment, operation, training, funding, and intelligence sharing in executing their operations. The establishment of a collaboration between Boko Haram and AQIM and later Al-Shabaab was first noticed by the Head of the African 


\section{Stanley Ehiane}

Command (AFRICOM), General Carter Ham (Ehiane 2017). The Carter Ham report was confirmed by Algeria's Deputy Foreign Minister, Abd-el-Kader Messahel, when he said, 'We have no doubts that coordination exists between Boko Haram and Al-Qaeda' in terms of operation and intelligence (Ehiane 2017: 118). The logistical networks among the groups, particularly Boko Haram, and the sharing of a similar ideology with the Islamic State has strengthened the activities of the extremists in Northern Nigeria.

Radicalisation as a concept in politics has failed to get consensus on a unified definition among scholars, as the threat challenges global security. The definitions of radicalisation by scholars are overwhelmed with limited and varying definitions that are often vague, ambiguous, and unsuitable for adoption. An operational definition of radicalisation was given by John Hogan, as it imbedded the elements of radicalisation for this study. Hogan defines radicalisation as a 'social and psychological process of incrementally experienced commitment to an extremist political or religious ideology' (Horgan 2009: 15). This definition X-rays the required components of radicalisation (i.e. process, incremental, and commitment). Similarly, radicalisation can also be conceptualised as the transition within an individual or group from passive reception of a revolutionary idea or belief to 'active pursuit of these ideas by imploring violence to achieved goals' (Onuoha 2014:2). To scholars like Onuoha (2014), radicalisation is the pathway to terrorism, but it is difficult to determine at what point a radicalised individual possibly becomes violent. However, except for in an extreme case, it is difficult for a sympathised individual to swiftly move to violent acts, like terrorism and suicide bombing, without being radicalised.

These elements of radicalisation are therefore necessary as they as serve as the basis for the understanding of radicalisation among Boko Haram members in Nigeria. Be that as it may, individual or group radicalisation is assumed to be unique to each context, this has strengthened the complexity behind a single definition of radicalisation. The process of radicalisation is initiated through changes in self-identification as a result of grievances reinforced by personal or group concerns on local or international issues (Sodipe 2013). The grievances are meant to inject a sense of alienation in individuals who deliver a cerebral opening for radicalisation. This cognitive reaction makes an individual or group have a new perception of the world. However, if the individual or group integrates into their society of peers with a similar orientation, there is a possibility of violent attacks, even though not 
all radicalised individuals are violent extremists. In the case of Boko Haram, they are being motivated through religion, but there are other sociological and psychological precipitating factors which induce grievance due to alienation and disenchantment (Onuoha 2014). Hence, radicalisation occurs due to the complex overlapping of factors which manifest differently in individuals and groups. In Nigeria, the disadvantaged youths, in terms of socio-economic provision, particularly in the Northern part of the country, have been more vulnerable to extremist views as they lack the cognitive capacity to query extremist ideology. In the light of the foregone, this study examines social issues, such as how a lack of education has inclined the youth's susceptibility to radicalisation and extremism.

\section{Youth Susceptibility to Radicalisation and Extremism}

Islam started in the seventh century and reached the Northeast of Nigeria in the eleventh century, spread peacefully by Muslim clerics and traders to the Northwest, particularly Kano and Katsina (ASCL 2020). However, with the Muslim revival which took place in Western Africa in the eighteenth century was led by Uthman dam Fodio, the Fulani scholar who already adopted Islam launched a jihad in Nigeria (ASCL 2020). The jihad, which took place from 1802 to 1812, led by Usman dan Fodio in Sokoto Caliphate, was to purify Islam and end all innovation contrary to the Qur'an and Sharia, across Northern Nigeria to Niger. The revolution united all the northern states under Sharia law, which automatically united the Hausa dynasties with the Sokoto Caliphate in 1812. However, the Caliphate Islamic legal system, based on Sharia law, was retained, even when it was incorporated into the colony of Nigeria. Though the jihad was religiously inclined, one cannot claim that the revolution did not have political elements of state formation, considering the unification between the Hausa and the Fulani.

However, an effort to impose the religious ideology on a secular, independent Nigeria, occasioned a series of Islamic fundamentalist groups, such as the Maitatsine group and Boko Haram, now the Islamic State of West Africa (ISWA). This fundamentalist group has embraced fierceness as a weapon of operation (Ehiane 2017). It is arguably deemed justifiable that the majority of the group's members and foot soldiers are made up of uneducated and poor youths called Almajiris (Qur'anic school pupils) (Olorunfemi 2013). Appreciatively, understanding the Almajiri is also not limited to the social and 
economic characteristics of the said foot soldiers of Boko Haram. The term Almajiri originates from the Arabic context of Al-Muhajir, which connotes a seeker of Islamic knowledge (Fowoyo 2013). Its origin refers to cohorts 'the holy prophet Muhammed who indeed migrated with the prophet from Mecca to Medina' (Onifade 2015: 10). These emigrants had no means of livelihood, upon arrival at Medina. Onitade (2015) observes that the migrants were Qur'anic knowledge seekers, as they move from one place to another regardless of their age or status. In the Northern part of Nigeria, where the Almajiri is situated, they seek and acquire Qur'anic knowledge through memorising the Holy Qur'an under a Qur'anic scholar-teacher (Mallam) (Yusha'u et al. 2013). The Almajiri live in horrific conditions, with or without parents and homes, roaming the streets for survival.

The Almajiri style of education in Borno, which started in the $11^{\text {th }}$ century was due to the interest of the Borno rulers in acquiring Qur'anic knowledge. Over time, this system of education found its way into other parts of Northern Nigeria. The Almajiri educational system is highly revered by those living in the Northern part of Nigeria, in terms of, 'morality and spiritual endowment' (Awofeso, Ritchie \& Degeling 2003: 314). One notable fact about the Mallam is that they never reject pupils, and they should accept any child brought to them by their parents or guardians. Nevertheless, little was provided for the children's up-keep by their parents or guardians. This placed a huge burden on the Mallam (Onifade 2015). Over time, the number of Almajiri increased and the Mallam could not care for them. Consequently, this resulted in begging for alms for the children's upkeep. Many Almajiri is found on the Nigerian streets, singing and begging from passers-by for alms and food (Sule 2002). According to Olorunfemi (2013), the introduction of formal education by the colonialists destroyed the Almajiri educational system. Coincidently, 'the colonialist transformation, the economic depression, urban migration, and commercialisation of the formal education over the years, made education, not within the reach of the poor' (Onifade 2015:11). In Katsina, the Almajiri education collapsed when the colonial administration stopped giving support to Islamic education in 1922, following the establishment of the first teacher training college in Katsina. The Almajiri, together with their Mallam, having no financial support, to begging and other menial jobs for survival. This is certainly the genesis of the predicament of the Almajiri system today. The unpleasant economic conditions in the Northern part of Nigeria responsible for massive youth illiteracy, as education was not affordable, and at the same time, 
was unattractive to the underprivileged (Olorunfemi 2013). The Almajiri schools are either situated by mosques or in the Mallam's house and usually have no study facilities other than a slate for writing (Zakir et al. 2014). Their studies take place in a deplorable, untidy environment and their social marginalisation means that they cannot afford health services (Zakir et al. 2014).

In recent times, the Almajiri practice can be considered child abuse and it is common among the poor, illiterate, and polygamous homes in Northern Nigeria (Olorunfemi 2015). However, in some instances, the Mallams do not permit their children to associate themselves, as a result of their social marginalisation (Kabir 2002). It is also worth observing that the children of the Mallam do not attend Almajiri Qur'anic schools; rather, they attend conventional schools where they acquire a Western education (Zakir et al. 2014). In a way, this is ironic, as one may consider the perpetuation of the Almajir's conditions by the Mallam and the political class for political goals. In the recent past, Almajiri has been brainwashed and used by both the religious and political class as thugs during religious crises and elections. They have, on various occasions, been abused, considering their socio-economic conditions. One would expect the Mallam and the political class to lead by example. Unfortunately, the continuous socio-economic conditions, particularly the lack of education, that is bequeathed to the youth in Northern Nigeria increases their vulnerability to extremist radicalisation and recruitment. Aside from the Almajiri, who are recruited members of the Boko Haram group, members are also drawn from university undergraduates, graduates, and migrants from neighbouring countries such as Chad and Cameroon. Some of the students that constitute the sect's members withdrew from their various institutions while the graduated ones tore up their certificates to enlist in the sect (Onuoha 2010).

Consequent upon the Almajiri's unhealthy educational system, the former president, Goodluck Jonathan, launched the Tsangaya model school programme at Gaji in Sokoto State on 10 April 2012 (Guardian Newspaper, 2019). The Jonathan administration spent 15 billion Naira on the construction of more than 100 model schools in the North to reduce the number of Almajiri roaming the streets (Guardian Newspaper, 2019). The government developed a guideline for educational integration, to strengthen the Almajiri educational system by integrating with the existing basic education structure (Onifade 2015). Onifade observes that the objective of an integrated educational system is to introduce some Western educational subjects into the Qur'anic system and to stop teenagers begging in the streets and being forced into hard labour. The 


\section{Stanley Ehiane}

schools which were founded on a modernised curriculum that blends Western and traditional models of Islamic education were built to tackle the high rate of illiteracy and reduce the number of out-of-school children in the North. The government commenced the integration programme by constructing several Almajiri model schools and establishing Universal Basic Education (UBE) and the Tertiary Education Trust Fund (TETF) to support a collaborative educational system (Onifade 2015).

However, like other institutions, the present integrated system is equally overwhelmed by issues of inadequacy with regards to well trained and qualified teachers, poor funding, poor sanitation, and inadequate infrastructure for learning (Ehiane 2017). The integrated programme, according to Ahmed Modibbo, a former executive secretary of the Universal Basic Education Commission (UBEC), also failed because the Northern governor wanted to be given cash to construct the classrooms (Ahmed Modibbo 2019). The Governors left and the schools were abandoned and vandalised when they had to undertake the finance and control over the project themselves (Ahmed Modibbo 2019). These challenges to sustain the integrated educational programme left the pupils returning to their old ways of roaming the streets, vulnerable to radicalisation and extremism (Onuoha 2014). However, the present administration of President Muhammadu Buhari has shown no commitment to the Tsangaya model school programme. In the light of the above, it is necessary to understand that this study uncovers the vulnerability of the youths to radicalisation and extremism and the need for formal education as a clinical intervention in peacebuilding in the Northern region of Nigeria.

\section{The Theoretical and Conceptual Synthesis}

The ecological system theory, developed by Urie Bronfenbrenner, explains how human development is influenced by different types of environmental systems, which pose as the opportunity and risk associated with why youths are inclined to be radicalised for violent extremism (Ettekal \& Mahoney 2017). As put forward by Bronfenbrenner, the developmental process involves a system of interactions within individual and between individuals and the environment, where an individual is a part of the environment over a space of time. In this circumstance, there are four interrelated levels of the environment within which an individual interacts according to Bronfenbrenner, the microsystem, mesosystem, exosystem, and macrosystems. 
Figure 1, the Nested Model of the micro-, meso-, exo-, and macrosystems in Bronfenbrenner's Ecological Systems Theory with Formal Education Acquisition in Northern Nigeria, is presented below.

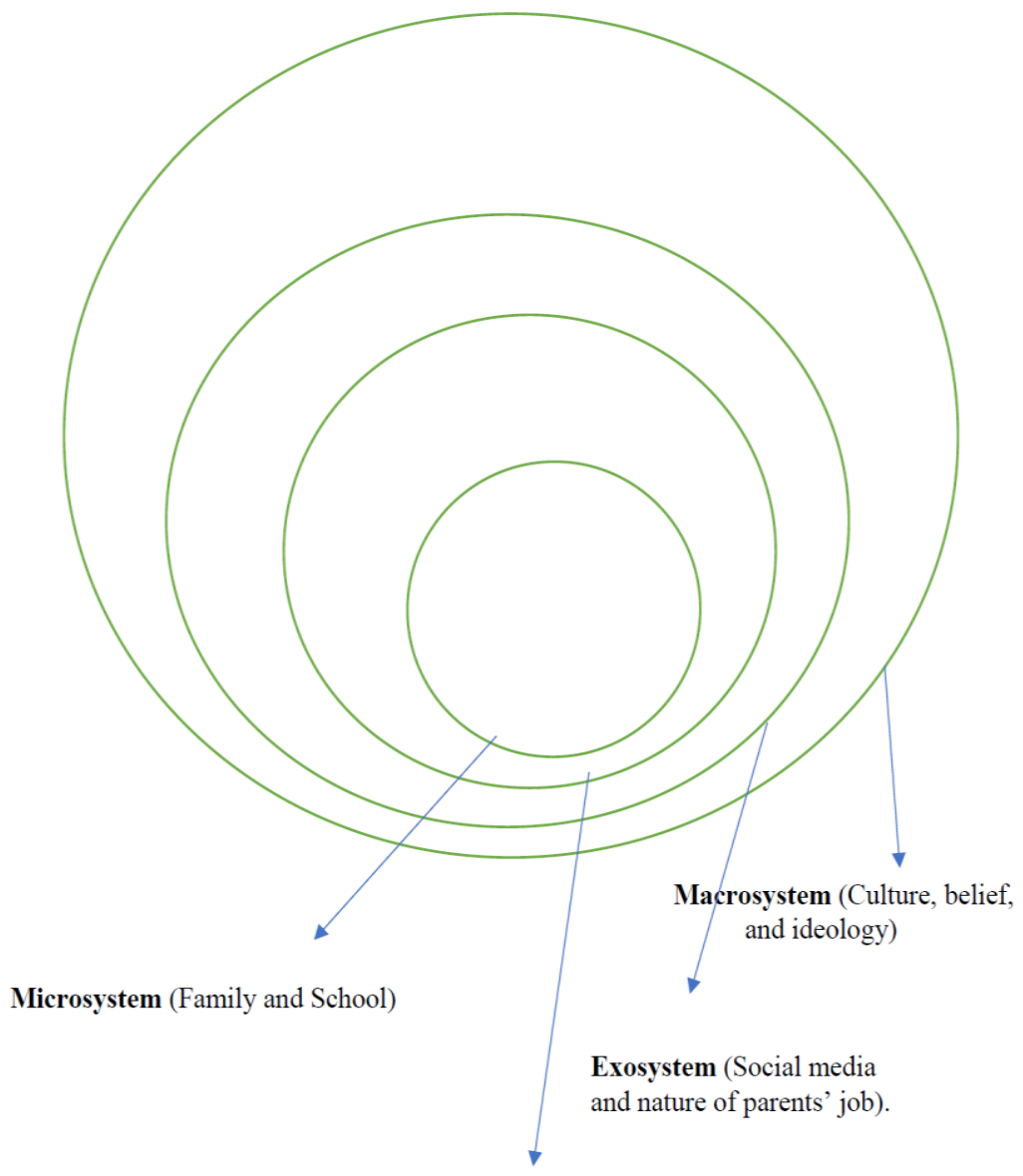

Mesosystem (Environment where those in the microsystem e.g. school interact and influence one another)

Figure 1: Bronfenbrenner's Social-Ecological Framework (1979) 
Drawing on Brofenbrenner, these levels of human interaction include a small system (microsystem), which is an interaction and relationship a child has toward his immediate environment, such as the family, school, mosque, church, and peers.

The mesosystem entails the interactions that occur within multiple microsystems and how the interactions affect a child's development (Ettekal $\&$ Mahoney 2017). A good example is an interaction between the child and the parents, school, church, and the effects on the child's development.

The exosystem refers to some interactions that indirectly affect the child's development. An example of such interactions are the nature of work of the child parents and the impact of social media. When the nature of the work of a child's parents interacts with the child's development, it affects the quality of time and attention a child receives from their parents. The exosystem simply expresses influences in child development through other people and things that are involved in the children's lives.

The macrosystem is the largest system in a child's environment and it encompasses cultural values, customs, structure, ideology, and laws that dictate the func-tioning of the system (Ettekal \& Mahoney 2017). The effect of some principles that are well defined in the macrosystem will have multiplier effects in the interactions of all other levels.

In the ecological theory, a child is in the middle and the interaction is dual, such that both the child and the environment influence each other. For example, if parents imbibe a culture of enrolling a child in an Arabic school as opposed to acquiring formal education, that culture is unlikely to provide resources and support for the acquisition of formal education. Hence, the parents' inability or ability to perform their function within the child's macrosystem is likely to be affected and this condition apparent in Northern Nigeria. when a child is in an environment where formal education is an integral part of development such a child will be left with no other choice than to be educated. The youths in Northern Nigeria live in the region where Arabic education prevails and against Western education. Hitherto, some of the institutions the youths interact with such as schools, mosques and peers have accepted Arabic education as dominant scholarship, hence they are left with no alternative than to embrace the Arabic education.

However, in applying the theory, the study raises questions about the lack of education as a factor that motivates youth radicalisation and extremism. Therefore, education is considered as an event in the microsystem level of the 
theory which inclines youths' extremism. In Northern Nigeria, there is a poor acquisition of formal education as many households encourage children to attend Arabic schools. The Northern region is affected most by poor education and most youths are recruited into extremism as they lack a Western-style of education which might have afforded them the capacity to challenge the extremist ideology. Thus, the Almajiri also fall into this category of Arabic learners, considering their background and current trends. In the case of the relationships in the mesosystem, there is already a strong interaction between the parents and the Arabic education teacher (Mallam). Since many of the parents acquired the same Arabic education, it has become a culture that a child must learn Arabic, and this diminishes support for formal education. Arabic education has been fostered by both the parents by their Islamic religious practices in Northern Nigeria. Formal education addresses issues of human rights, and of course, could have empowered youths to query extremist ideas, which goes against the Arabic education that portrays respect and obedience to a higher authority. Besides, some extremists abhor Western education, which they believe has brought a lot of negative social vices, such as corruption. Hence, Western education is discouraged and considered forbidden in its totality. This illustrates the impact of beliefs, values, and attitudes in the macrosystem that influences the interactions in one's micro-, meso-, and exosystem, which furthermore have a greater impact on the youths' interactions with their environments.

The conceptual framework outlined above, then sets out the different components that are central to understanding youths' vulnerability to extremism and radicalisation in Northern Nigeria, due to the lack of formal education. Conceptually, the theorisation of the study falls within the prominent work of Bronfenbrenner. It is concerned with the impacts of various environmental systems on human development. The study of the roles of education in fostering social cohesion and peacebuilding and development, where a lack of quality of formal education, has created a fertile ground for extremist recruitment.

\section{Global and Regional Frameworks on Peace Education}

However, to achieve global peace and freedom, there are a series of global and regional frameworks on the need for equitable and quality education. The United Nation's (UN) agenda 2030 Sustainable Development Goals (SDG), 


\section{Stanley Ehiane}

and the African Union Agenda 2063, are meant to transform the globe and the entire African continent by building a peaceful and inclusive society (SDG, 2015). In 2015 world leaders from 193 countries converged to agree on a joint plan, called the Sustainable Development Goals (SDGs), with the vision to transform the world into one free of war, poverty, drought, and famine by the year 2030. The SDG is comprised of 17 integrated and invisible goals stated below:
1. No Poverty
2. Zero Hunger
3. Good Health and Well-being
4. Quality Education
5. Gender Equality
6. Clean Water and Sanitation
7. Affordable and Clean Energy
8. Decent Work and Economic Growth
9. Industry, Innovation, and Infrastructure
10. Reducing Inequality
11. Sustainable Cities and Communities
12. Responsible Consumption and Production
13. Climate Action
14. Life Below Water
15. Life on Land
16. Peace, Justice, and Strong Institutions
17. Partnerships for the Goals (SDG 2015)

Goal 4 fits into the discourse of this study. Ensuring and acquiring quality education will help grant the appropriate knowledge and skills such as human rights, promote a culture of peace and nonviolence, and allow for the appreciation of cultural diversity to promote sustainable peace and development. The goal also includes the availability of trained teachers and the provision of adequate facilities in primary and post-primary education, particularly in Africa where violent conflicts have ravaged some countries. This United Nations 'blueprint' to achieving global education for a sustainable future also furthers strengthening the African Union Agenda 2063.

The Pan Africanist vision of 'an integrated prosperous and peaceful Africa, driven by its citizens, representing a dynamic force in the international 
arena' (AU 2015: 11), still stands. In achieving the Pan Africanist vision, the AU on its golden jubilee in May 2013 solemnly outlined the 'Africa We Want' Agenda, 2063. The Agenda itemised seven aspirations, each with their objective. The AU'S aspirations for Africa We Want (AWW) are stated below:

1. A prosperous Africa based on inclusive growth and sustainable development.

2. An integrated continent politically united and based on the ideals of Pan-Africanism and the vision of Africa's Renaissance.

3. An Africa of good governance, democracy, respect for human rights, justice, and the rule of law.

4. A peaceful and secure Africa.

5. Africa with a strong cultural identity, common heritage, shared values, and ethics.

6. An Africa whose development is people-driven, relying on the potential of African people, especially its women and youth, and caring for children.

7. Africa as a strong, united, and influential global player and partner (AU 2015: 2).

However, in line with the objectives of this study, aspiration four, which stresses peace and a secured Africa, fits into the discourse of forms of motivation for violent extremism and radicalisation. Hence, a culture of peace and tolerance could be nurtured among African children and youth through peace education (AU 2015). The management of diversity (Culture, religion, beliefs, and tradition) through education across Africa, Nigeria inclusive, will enhance harmony, improve human rights, and sharpen the reduction in violent conflict. The AU aspiration goal four is meant to promote human and moral values by rejecting all forms of violent extremism or terrorism, irrespective of their motivation, such as education in the case of Nigeria. The significance of education in countering violent extremism has been emphasised through the global and regional frameworks for sustainable peace and development. Hence, clinical intervention on the role of education in countering radicalisation and extremism becomes necessary. It is assumed that human beings can change violent behaviour and beliefs. Based on this assumption peace is built by teaching alternatives to violence and exposing the consequences of violence. Peace education is a strategy that is infused into all the other strategies of peace in a 
country such as peace through sustainability, transformation, and justices. Therefore, the international frameworks stressed on the impact of education in peacebuilding particularly across Africa, where illiteracy plays out.

\section{The Role of Education in Countering Violent Extremism: Clinical Intervention}

Scholars over the years have not been able to discover a direct link between education and violent extremism and radicalisation. The difficulty in establishing the correlation could be attributed to the fact that violent extremism and radicalisation are political concepts rather than scientific ones, which would complicate reliable data gathering if a study were to be conducted. Hitherto, the study of violent extremism and radicalisation is diverse as the reasons why individuals and groups engage in the diverse conflict. It should be noted that a study of this nature should be contextualised, considering the diverse nature of the concepts under exploration as quality education could become a means to an end itself. However, the unfolding events of radicalisation and extremism over the years in Nigeria, and the context in which the violent extremism unfolds, justify that a relevant education of good quality could reduce or hinder the recruitment and proliferation of violent extremism in Nigeria. Education empowered youths can challenge and intercept an individual with an extremist and radical ideology. The school system teaches issues such as faith, radical political thought, culture, religion, law enforcement, and other typical tools to support and transform society for peaceful coexistence. There is no doubt that it injects a high level of civic values which increase adherence to social norms and are less attracted to violent groups but rather promote peace (UNESCO 2017). Nigeria is a society with diversities (religion, culture, ethnic, and language), the widespread of the teaching of civic responsibility across the country will build a shared sense of diversity among the youth.

Education can have a substantive impact on the prevention of violent extremism through strong educational policies and practices (UNESCO 2017). The integrated curriculum system of education introduced by the Goodluck Jonathan administration reflects a good example of inclusive education (SDG 2015). The integrated study system could bridge the gaps between Western and traditional models of Islamic education and assist the Almajiri in their struggle against poverty and social alienation, thereby promoting social cohesion. 
However, as illustrated in the framework above, the impact of beliefs, values, and attitudes in the macrosystem influence how the interactions in one's micromeso-, and exosystem will be diffused to accommodate diversity (Ettekal \& Mahoney 2017). The success of the integrated education programme depends on how soon the present regime of Muhammadu Buhari addresses the current issues facing the integrated system, such as the lack of qualified teachers, adequate infrastructures, and funding. These pending problems can best be resolved with the cooperation of the governors of the affected states and the federal government.

Despite the age-long debates on the link or non-link between psychosocial conditions and radicalisation and extremism, at a pedagogical level, (primary and secondary) when pupils are most likely to start interacting with radicalised ideas, socio-emotional and behavioural skills should be developed (De Silva 2917). The need for the development of learners' socio-emotional and behavioural skills, besides cognitive skills, are significant in ensuring that the youth become more aware of their diverse society and create a sense of investment in their future. Well-developed socio-emotional and behavioural skills in a country like Nigeria will help through an effective partnership among the youth, regardless of diversity. Also, it will create a sense of shared responsibility among the youth for their safety and development.

Lastly, the government's educational intervention requires firm cooperation between the federal government and the state government under the umbrella of good leadership. Corruption has been identified as one of the failures of the integrated educational system which could have benefitted the Almajiri. Addressing issues of national interest, such as good and quality education, requires high levels of cooperation among the various levels of government as well as good leadership. Government is not exonerated when considering the factors responsible for the youth's vulnerability to extremism and radicalisation when leadership has been compromised. The need for strong leadership and cooperation between the state and the federal government is significant in achieving quality education for peaceful coexistence.

\section{Conclusion}

This article focused on the lack of education as a condition for youths acquiring radical and extremist ideologies in Northern Nigeria. It sheds light on the genesis of extremism in African and its spread across the continent. The article 


\section{Stanley Ehiane}

outlined and discussed the concepts of radicalisation and extremism and the rise of Islam in Nigeria. It further discussed the jihad revolution across Northern Nigeria and the introduction of Sharia and the genesis of Almajiri and their social-economic conditions. The study variables and possible relationships were established using the ecological system theory developed by Urie Bronfenbrenner in 1979. The theory justifies how and why a lack of education remains an important condition for the youth's vulnerability to extremism and radicalisation. However, the study did not establish a direct link between the lack of education and extremism but rather identified it is a means to extremism and radicalisation as it plays out in the case of Northern Nigeria. Youths fall prey to extremism and radicalisation in Northern Nigeria due to a lack of education, and most of them form the largest forces of Boko Haram's foot soldiers.

The study analysis is also strengthened by regional and global frameworks, such as the United Nations (Sustainable Development Goal 2015) and African Union Agenda 2063, to justify the relevance of education in achieving peace and security. Hitherto, the study examined the substantive efforts of the previous government, particularly the launching of an integrated educational system to address the issues regarding education to prevent a pool of youths resorting to extremism. The integrated education collapsed due to economic and political reasons. Addressing the condition of the youth's acquisition of extremist ideology, the study proposed some clinical interventions to further prevent the youth's inclination for radicalisation and extremism in Northern Nigeria. It is hoped that this piece has made it clear that a lack of education is not a direct cause of extremism and radicalisation but a means, and if the issue is addressed there will be a significant reduction in the youth's vulnerability. The author hereby proposes a scientific approach in future studies by considering the varied causes of radicalisation and extremism.

\section{References}

African Studies Centre Leiden, ASCL 2020. Islam in Nigeria. Available at: https://www.ascleiden.nl/content/webdossiers/islamnigeria\#History\%2 0of\%20Islam\%20in\%20Nigeria (Accessed 15 April 2020.)

African Union [AU] 2015. Agenda 2063. The Africa We Want. Available at: https://www.un.org/en/africa/osaa/pdf/au/agenda2063first10yearimplementation.pdf (Accessed 19 April 2020.) 
Ahmed Modibbo 2019. Northern State Governors Frustrated the Integration of the Almajiri School System with Basic Education. Available at: https://www.thecable.ng/ex-ubec-es-northern-govs-frustratedjonathans-almajiri-project-because-of-money (Accessed 18 April 2020.) Al-Mahri A.B. (ed.). 2006. Milestones. England: Maktabah Publishers. Awofeso, N.J., J. Ritchie \& P. Degeling 2003. The Almajiri Heritage and the Threat of Non-state Terrorism in Northern Nigeria - Lessons from Central Asia and Pakistan. Studies in Conflict and Terrorism 26,4: 311 325. https://doi.org/10.1080/10576100390208260

De Silva, S. 2017. Role of Education in the Prevention of Violent Extremism. Working Paper World Bank Group. Available at:

http://documents.worldbank.org/curated/ n/448221510079762554/Roleof-education-inthe-prevention-of-violent-extremism (Accessed 22 April 2020.)

Ehiane, S. 2017. Terrorism in Nigeria, 2010-2015: Causes and Challenges. $\mathrm{PhD}$ thesis, University of KwaZulu-Natal, South Africa.

Ettekal, A. \& J. Mahoney 2017. The Ecological System Theory. In Peppler, K. (ed.): The SAGE Encyclopaedia of Out-of School Learning. London: SAGE Publication.

Fowoyo, J.T. 2013. Transforming the Almajiri Education for the Benefits of the Nigerian Society. Journal of Education and Social Research 3,9: 2554. Available at:

https://www.mcser.org/journal/index.php/jesr/article/view/2319/2294 (Accessed 18 ${ }^{\text {th }}$ April 2020.)

Horgan, J. 2009. Walking Away from Terrorism: Accounts of Disengagement from Radical and Extremist Movements. New York: Routledge. https://doi.org/10.4324/9780203874738

Idris, M. 2019. War for Peace: Genealogies of a Violent Ideal in Western and Islamic thought. UK. Oxford University Press.

https://doi.org/10.1017/S1537592719004845

Lawrence, B. (ed.). 2005. Message to the World: The Statements of Osama Bin Laden. New York: Palgrave Macmillan.

Olorunfemi, A. 2013. Boko Haram's Tactics, Targets, and Arsenals of Terrorism. African Journal for the Prevention and Combating of Terrorism 4,2: 32 - 52 .

Onifade, I.T. 2015. A Pilot Study of the Challenges of Infusing Almajiri Educational System into the Universal Basic Educational Programme in 
Sokoto, Nigeria. Journal of Education and Practice 6,16: 10 - 16.

Onuoha, F. 2010. The Islamist Challenge: Nigeria's Boko Haram Crisis

Explained. Africa Security Review 19,2: 1 - 15. Available at:

http://www.tandfonline.com/loi/rasr20 (Accessed 23 September 2020.) https://doi.org/10.1080/10246029.2010.503061

Onuoha, F. 2014. Why do Youth join Boko Haram? Special Report.

Washington, DC: US Institute of Peace.

Sharif, T.A. \& J. Richards 2016. Towards a Continental Strategy for

Countering Violent Extremism in Africa. New York: Global Peace

Operations Review. New York Center on International Cooperation.

Available at:

http://peaceoperationsreview.org/thematic-essays/towards-a-

continental-strategy-for-countering-violent-extremism-in-africa/

(Accessed 10 ${ }^{\text {th }}$ April 2020.)

Sodipo, M.O. 2013. Mitigating Radicalism in Northern Nigeria. African

Security Brief. 26: .1-8. Available at:

Sule, A.K. 2002. The Almajiri Phenomenon: Study of the Youth in

Traditional Quranic Scholarship in Northern Nigeria. Seminar presentation notes for the Almajiri initiatives, UDU Sokoto, Nigeria. The Humanities Journal 1,1: 27 - 47.

Sustainable Development Goals (SDG) 2015. Transforming our World: The 2030 Agenda for Sustainable Development. Available at:

https://sustainabledevelopment.un.org/content/documents/21252030\%2

0Agenda\%20for\%20Sustainable\%20Development\%20web.pdf

(Accessed 19 April 2020.)

The Guardian 2019. Jonathan's N15b Almajiri Schools Rot Away.

United Nations Children's Fund (UNICEF) 2016. Evaluability Assessment

Report. Available at:

https://www.unicef.org/nigeria/media/1421/file/Nigeria-evaluabilityassessment-report-UNICEF-training-investments 1.pdf (Accessed 12 May 2020.)

United Nations Children's Fund (UNICEF) 2019. Every Child Learns:

UNICEF Education Strategy 2019-2020. New York. Available at:

https://www.unicef.org/media/59856/file/UNICEF-education-strategy-

2019-2030.pdf (Accessed 10 May 2020.)

United Nations Development Programme (UNDP) 2017. Journey to

Extremism: Drivers, Incentives, and Tipping Point for Recruitment. 
Available at:

https://journey-to-extremism.undp.org/content/downloads/UNDP-

JourneyToExtremism-report-2017-english.pdf

(Accessed 13 April 2020.)

United Nations, Scientific and Cultural Organisation (UNESCO) 2012. Hope for Nigeria. Available at:

https://unesdoc.unesco.org/ark:/48223/pf0000222483

(Accessed 10 May 2020.)

Yusha'u, M.A., A.K. Tsafe, S.I. Babangida, N.I. Lawal 2013. Problems and Prospects of Integrated Almajiri Education in Northern Nigeria. Scientific Journal of Pure and Applied Science 2,3: 125 - 134.

Zakir, A., U. Abubakar, U.S. Lawal, H. Imrana, I.T. Habibu, I.H. Hassan \& M.M. Haranda 2014. The Practice of Almajiri. Prospect and Sociomedical Challenges in the Northern Part of Nigeria 6,7: 128 - 131. https://doi.org/10.5897/JASD2014.0273

Stanley Ehiane

Fort Hare Institute of Social and Economic Research (FHISER) University of Fort Hare Eastern Cape, South Africa Stanleyehiane@yahoo.com 